\title{
Teacher Leadership: Promoting a Reflective Practice Model
}

\author{
Endah Yanuarti \\ SMEC, School of Education Curtin University \\ Western Australia \\ endahyanurati@postgrad.curtin.edu.au
}

\author{
David F. Treagust \\ SMEC, School of Education Curtin University \\ Western Australia
}

\begin{abstract}
This paper focuses on the development of a reflective practice model for secondary teachers because it is related to the context of teacher competence standards in Indonesia. The research used a qualitative interpretive approach to examine the teaching practice of secondary school teachers who were the participants of the study. Classroom observations of participants' teaching and learning process were videotaped and interviews with teachers were the major data sources. The participants showed various conditions in delivering the lessons with respect to their ability in developing and managing the lesson and the classroom and their roles as a leader in the classroom. Teachers involved in developing the reflective practice model showed improvement in managing the lesson and classroom. Reflective conversation is one of the important keys in the developed model. Three of eight the participants demonstrated the enhancement of their lesson delivery reflecting on their practice. This model has implication for dissemination to teachers in other Indonesian schools in the future.
\end{abstract}

Keywords- Reflective practice model, teacher competence standards, leader in the classroom

\section{INTRODUCTION}

Even though reflection is closely related to leadership, this is not realized by teachers. Most teachers did not realize that they are a leader to their students. The perception arises in teachers' perspective that leadership in the school primarily belongs to a school principal. In Indonesia, the school principal has an additional role for teachers to be leaders also in order to improve the quality of education. [1] Goleman [2] suggested that every person can demonstrate leadership although not everyone can be a leader. This idea is also supported by [3] who writes that all teachers are potential leaders based on his concept of 'leadership density'. He argued that large number of people are involved in the work of others; for example, in the school, teachers are trusted with information, involved in decision making, are exposed to new ideas and participate in knowledge creation and transfer. This paper discusses the notion of reflective practice in regards to Indonesian educational policy, teachers' leadership and a model of reflective practice developed during the study.

\section{A. Methodology}

In this case study, teachers are the main focus as the unit of analysis. [4, 5, 6] Eight secondary school teachers in a small urban centre were involved in the research to gain an in-depth study of their reflective practice. The interview guidelines were taken from the dimensions of reflective practice by Zwozdiak-Myer [7] to create reflective conversation.
The research sources are teacher interviews and records (videotaping) of classroom observations of their teaching and teachers' documents related to lesson plans and other probes of reflections (journals/diaries, classroom action research reports, etc.). As interviews were the major source of data to consider their reflective practice, the analysis focused on revealing the participants' meaning of reflective practice and the reasons behind their understanding.

The interviews were compared to the Teacher Competencies/Standards in Indonesia to examine the extent to which the teachers' practice met these dimensions. The videotapes were also used as a tool for reflection and triangulation. $[8,9,10]$

\section{REFLECTIVE PRACTICE IN INDONESIA}

A. Policy: Teacher Competency Standards

Teacher quality is the main focus of education in Indonesia that arose from two regulations in 2005 and 2007 that focused on teachers. The first is Constitution no. 14 about Teachers and Lecturers which, in general, describes professional identity, academic qualifications, competence and certification/incentive of teachers and lecturers. The second is the Regulation of Minister of National Education no. 16 which explains Teacher Competency Standards for four domains, namely: pedagogical skills, having good personality, having social awareness and professional practice that should be recognized formally by teachers.

Unfortunately, most teachers do not recognize the standards although they unknowingly apply them. According to [11], there are several reasons why teachers do not recognize teacher competency standards such as a long list of duties (several dimensions with many focus areas), opaque language (formal language need interpretation), generic skills (almost the same for primary, secondary and senior high school), decontextualized performances (the performance to which the standard refers is separated from the contexts in which it occurs), expanded duties (clash between teachers' conception of their work and system expectations), and weak assessments (the guide to assess the achievement of standards) (p. 123). That is why teachers do not realize the power of the word 'reflection' stated in the standards because it has an abstract meaning and must be translated into practices in order to be useful to the teaching practitioner.

\section{B. Teacher Leadership}

Teachers are directly connected and involved in student learning and its processes. [12] As the center of the school 
community, teachers have responsibility to help colleagues initiate, support, and sustain a community of learners and leaders. According to Katzenmeyer and Moller in [13], teacher leadership defines those who lead within and beyond the classroom, identify with and contribute to a community of teacher learners and leaders, and influence others towards improving their educational practice. Teacher leadership is also defined as the ability to encourage colleagues to change, to do things they would not ordinarily consider without the influence of the leader [14]. Those definitions imply that teachers are leaders in and outside the classroom. Inside the classroom, teachers have responsibility to manage the teaching and learning process, including the environment of learning, and the improvement of students in their learning process. Outside the classroom, their responsibility is more like to support and influence other colleagues in improving the school community. As Day and Harris [15] suggest, the teacher leadership role can be divided into four dimensions. The first dimension concerns about the interpretation of the principles of school improvement into the practices of individual classrooms. The teacher is responsible as a leader to ensure that the relationship between teachers and school is secure to maximize opportunities for professional development among teachers. The second dimension is focused on participative leadership where teachers should be involved in and part of the change or development of the school. There should be team work among teachers and they support each other for school's sake. The third dimension is the mediating role of teachers who have important sources of expertise and information. This role is crucial to school improvement both in the teaching learning process and in administration. The fourth dimension is to establish close relationships among teachers through mutual learning such as action research [16], peer classroom observation [17], or creating a collaborative culture in the school. [18] The point to be highlighted is that teacher leaders are expert teachers who spend the majority of their time in the classroom but take on different leadership roles at different times. [19]

By recognizing the area of weakness in their teaching, professional development training can be provided to strengthen the weakness area and develop the potential as a teacher leader.

\section{REFLECTIVE PRACTICE MODEL}

\section{A. Model of reflective practice by experts}

\section{1) Five Phases}

Dewey [19] proposed the five phases of reflective thought as the model of doing reflection. The first phase is suggestion, in which the mind leaps forward to a possible solution. The second is intellectualization where the difficulty or perplexity that has been felt or directly experienced into the problem to be solved. The third is hypothesis generation to use one suggestion after another as a leading idea and initiate and guide observation and other operations in the collection of factual material. The fourth is reasoning, the mental elaboration of the idea or supposition, in the sense in which reasoning is a part, not the whole of inference. The last phase is testing the hypothesis by overt or imaginative action ( $p$. 107). Dewey explained further that the phases of reflection would not be in fixed order but needs to consider the situation one is facing.

\section{2) Follow Me, Joint Experimentation, Hall of Mirrors}

Schon [20] proposes three forms of modelling as ways that students learn from their supervisor's practice. Those are hall of mirrors, joint experimentation and follow me.

The model starts from Follow $\mathrm{Me}$ where experienced practitioners demonstrate and describe their pedagogical knowledge to teachers. Teachers then can imitate the use of pedagogical knowledge and doing the similar ways as their practice. Discussing the actions with the experienced practitioners and reflect from teachers' perspectives is very important so that teachers can learn the practice setting. [21]

The Joint Experimentation model encourages teachers to take the lead in reflective inquiry. The experienced practitioners then follow the teachers' line inquiry, commenting, advising, and offering alternatives when teachers question the problem that occurs in their setting.

The Hall of Mirrors model focused on the practices of experienced practitioners and teachers as an example of what teachers are attempting to understand and develop in their own practice. The important issue is that teachers can experience what it means to be a learner in a practice situation and it is anticipated that teachers can reflect their position later in their practices.

\section{3) Critical Model}

Brookfield [22] encourages teachers to look at their practices from four different perspectives or lenses, namely autobiographies as learners and teachers, students' eyes, colleagues' experiences and theoretical literature.

O'Connor and Diggins [23] describes more about Brookfield's model in that through autobiographies as learners and teachers, teachers can be expected to refer to their own education and experiences and develop their skills in daily practices. Teachers' own experiences in their education life can influence their values and assumptions about teaching ( $\mathrm{p}$. 41) and will shape their beliefs, values and characteristic in their teaching styles. By reflecting on their experiences as learners, teachers can help themselves to uncover certain aspects of their practice especially the 'feel' of the joyful learning of their students' based on their own experiences as learners and the development of the strategies and methods of their practice.

The second lens focused on how teachers can collect students' perspectives towards their lessons or activities or incidents. By recording students' comment and reactions of certain activities, teachers can gain perspectives of certain topics or strategies that they develop and reflect on them. Teachers can position themselves as learners in viewing the experience.

The third lens offers perspectives from colleagues' experiences as a comparison to teachers' own reflections. A reflective conversation with colleagues can expose a similar situation experienced by others. Through discussion the 
experiences may provide solutions to overcome a perplex situation in the teachers' own practice.

The theoretical literature lens will help teachers to look at some points from the expert in guiding them to explain certain situations. It is a good perspective based on experts to reflect and gain answers in solving some problems that occur in their practice.

\section{4) Ecological Theory}

In the context of reflection, teachers' reflection might be influenced by certain situations such as individual matters, political issues, or school environment. To recognize the influences, teachers can step back and think deeply to overlook the situation. There are four levels of reflection according to Brofenbenner:

- Level one: reflect on teachers' personal context such as values, beliefs and assumption, and the origin of these elements.

- Level two: reflect on immediate learning environment such as the classroom, other adults, families and the local community.

- Level three: reflect on the requirements of certain standards (in Indonesia these are Teacher Competence Standards) such as the philosophy of settings, statutory requirements (desirable objectives and practices), and regulations.

- Level four: reflect on nation's values and beliefs about children and education (in Indonesia this is the National Education Purpose).

\section{5) Spiral Model}

O'Connor and Diggins [23] proposed a reflection neverending model called the spiral model. It is expected that teachers reflect constantly on their practice to continue to develop and grow in their profession (p. 47). The spiral model contains the following stages:

- Act. Teachers' teaching practice involves action.

- Select. Teachers select an action that has impacted on them during the day.

- Name. Teachers describe the action.

- Reflect. Teachers reflect using the description of the action, as well as considering values, beliefs, assumptions, other influences on the event, theory and the context of the event.

- Research. Teachers refer to theory to support your reflection.

- Plan. Teachers develop a plan as a result of the reflection.

- Act. Teachers implement the plan.

- Monitor. Teachers return to the beginning of the spiral and the process continues.

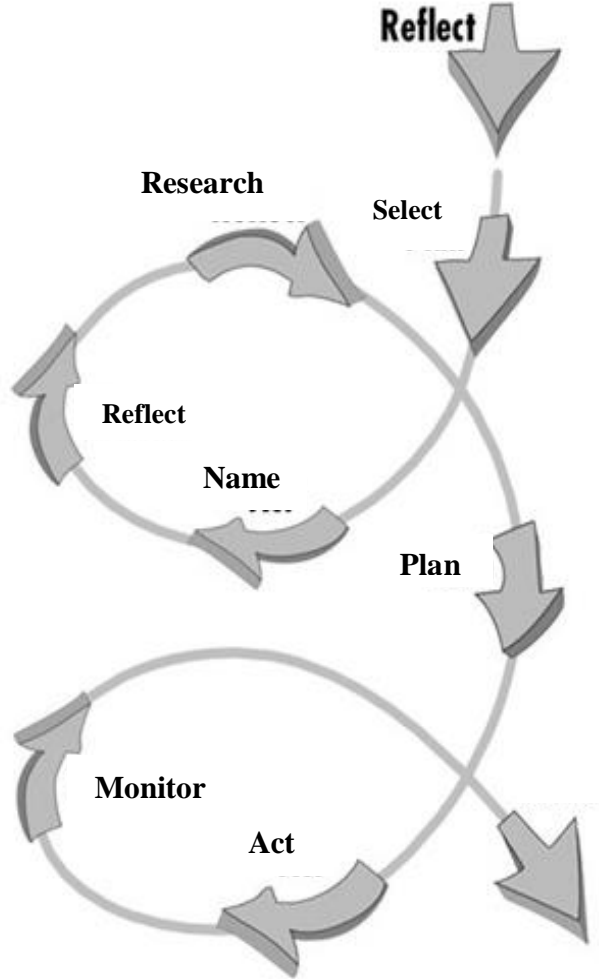

Fig. 1. Spiral Model of Reflective Practice

\section{B. Developing a model of reflective practice by research \\ 1) Reflective Conversation}

Ghaye and Ghaye [24] present an argument that reflective conversation is a medium to make teachers be able to learn and question their teaching practice from their experiences. They propose several points of reflective conversation that elaborate the meaning of the conversation. Reflective conversation is a special kind of discourse that take the form of 'conversation with self' (p. 20) but these conversation should be shared with others colleagues. It will open teachers' minds and construct their critical perspectives while commenting on others' experiences. Teachers share their experiences and discuss several issues happened during their teaching practice. They reflect on their experiences and take notes to 'repair' or find solution of perplex situation occurred in teaching and learning process.

\section{2) Observation}

Conducting classroom observations and giving feedback to teachers is useful. [25] And the role of the supervisors (or teacher trainers) should be to assist and promote the reflection process by providing input but refraining from taking over ( $\mathrm{p}$. 127). To give feedback without reflecting is insufficient as well. [26] He believes that feedback and reflection should be integrated in reflective conversation and the supervisors or facilitators should be assisted to guide teachers to do their reflections.

\section{3) Videotaping}

Using videotapes of actual teaching events and situations are assumed to offer teachers the opportunity to repeatedly observe teaching and learning in action. [27] It was considered that teachers would be nervous in the first recording and did 
not teach naturally. At the second recording, teachers adjusted their practices and still considered the researcher's presence. They would get used to in the third and the fourth recording. Teachers were nervous and excited because it was a new experiences for most participants considering that they were never been recorded before. Using videotapes to reflect on their teaching practice would be their first time experience as well.

\section{4) Discussion}

The discussion provides a focus on teachers' educational values. It is a private conversation but can be sounding to public as a reflective activity to shape teachers' work and transform what they do to improve educational experiences. The discussion is intended to make sense of teaching and learning, especially to interrogate teachers' experiences. It also has potential to enlighten and empower the teachers.

\section{5) Writing a Journal}

Writing a journal is an alternative way to engage in reflective practice. It is better if teachers write their own reflective journal as a diary. Bolton [28] suggests that reflective practice is a state of mind, an ongoing attitude to life and work that can enable professionals to learn from experience about themselves, their work, the way they relate to home and work, significant others and wider society and culture, the way social and culture structures are formed and control us. She promotes writing reflective journals because reflective writing is the reflective process. It captures events, individuals, thoughts, feelings and values and also creates closer contact with emotions, thoughts and experiences.

\section{6) Professional Development}

Being a teacher includes consideration as part of teacher practice to improve and refine one's teaching skills [29, 30, and 31]. In this way, reflective practice becomes an important indicator of professional competence of teachers [32, 33, and 34] and should be used for in-service education in Indonesia in relation to teacher standards. Unfortunately, most teachers do not document the ways in which they develop reflective thought so that they can analyze and interpret problems happening in their teaching practice. These documents can be their supporting document for their professional development in the future. [35] Teachers will benefit from their reflection by having better teaching performance, meaningful teaching and learning processes and opportunities to improve their continued professional development. [36]

\section{CONCLUSION}

The study demonstrated that interrogation through reflective conversation or interview can encourage teachers to reflect on their experiences. Most teachers confessed that they were relieved that they could speak up on their daily practice since no one asked them to do it. The videotape was also shown to be a useful tool for doing reflection because teachers could observe their own practice repeatedly and thereby improve their strategies.

Consequently, teachers need a certain model of reflective practice to assist and guide their teaching practice. This paper promotes a model of reflective practice for teachers in
Indonesia in relation to teacher leadership. Teachers can control the class if he/she is confident enough to deliver the lessons after they reflect and analyze their performance.

The role of supervisors is important and reflective conversation is the key for teachers to speak up about their own experiences and how they handle certain situations. Through this study, it is revealed that teachers can be reflective in a conversation that focused on their own practices. They can express, remember and reflect on what they have done during their teaching practice.

Based on the study, the author suggests the model of reflective practice as follows:

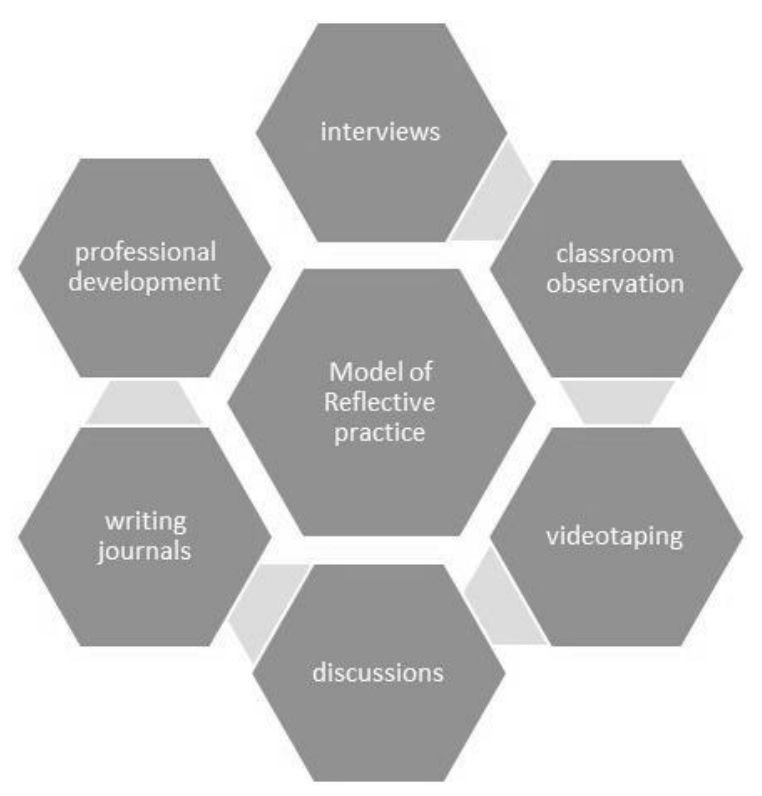

Fig. 2. A preferable model of reflective practice for Indonesian teachers

Figure 2 shows a preferable model of reflective practice in Indonesia. The interview is a proper way to explore teachers' experiences and inter-change views in conversing topic of the mutual interest [37]. Through interviews, teachers can reveal their own perspectives on their daily teaching practice. Another important thing in this model is discussion. These two activities are important, because teachers rarely express their personal teaching practice experiences that actually reveal their perspectives and open their minds to reflect. By interviewing and discussing, it is found out that teachers were very excited to describe their feelings, activities and barriers during their teaching practice. They can share experiences on certain methods and strategies and peer observations is welcomed for teachers who are eager to know the procedure of the method/strategy. By this model teachers' selfconfidence is rising and their leadership is demonstrated by the way they manage the classroom.

\section{REFERENCES}

[1] Ministry of National Education, Standar kualifikasi akademik dan kompetensi guru, Jakarta: The Government of Republic of Indonesia, 2007. 
[2] D. Goleman, The New Leader: Transforming the art of leadership into the science of results, London: Little Brown, 2002.

[3] T. Sergiovanni, Leadeship: What's in it for schools? London: Routledge Falmer, 2001.

[4] R. K. Yin, Case Study: Design and methods, CA: Sage Publishing, 1984.

[5] W. M. Tellis, 'Application of a case study methodology', The Qualitative Report, Vol. 3, no. 3, 1997.

[6] G. Thomas, How to do your case study: A guide for students and researchers, Thousand Oaks: Sage Publications, 2011.

[7] P. Zwozdiak-Myer, The teacher's reflective practice handbook: Becoming an extended professional through capturing evidenceinformed practice, New York, NY: Routledge, 2012.

[8] M. Lampert and D. L. Ball, 'Using hypermedia technology to support a new pedagogy of teacher education (Issue Paper 90-5)', East Lansing, MI: National Center for Research on Teacher Education, Michigan State University, 1990.

[9] R.T. Putnam and H. Borko, "What do new views of knowledge and thinking have to say about research on teacher learning", Educational Researcher, 2000, vol. 29, no. 1, pp. 4-15.

[10] J. Wang and K. Hartley, "Video technology as a support for teacher education reform", Journal of Technology and Teacher Education, vol. 11, no. 1, 2003, pp. 105-138, Norfolk, VA: Society for Information Technology \& Teacher Education.

[11] W. Louden, "Standards for standards: The development of Australian professional standards for teaching", Australian Journal of Education, vol. 44, No. 2, 2000, pp. 118-134.

[12] M. E. Krisko, Teacher Leadership: A profile to identify the potential, 2001, Orlando: Kappa Delta Pi.

[13] A. Harris, "Teacher Leadership as Distributed Leadership: Heresy, fantasy or possibility?" School Leadership \& Management, Vol. 23, No. 3, 2003, pp. 313-324.

[14] P. A. Wasley, Teachers Who Lead: The rhetoric of reform and the realities of practice, 1991, .New York: Teachers College Press.

[15] C. Day and A. Harris, "Teacher leadership, reflective practice and school improvement" in K. Leithwood and P. Hallinger (eds), Second International Handbook of Educational Leadership and Administration, 2003, Dordrecht: Kluwer Academic.

[16] R. L. Ash and M. Persall, "The principal as chief learning officer: Developing teacher leaders", NASSP Bulletin, May 2000, pp. 15-22.

[17] J. W. Little, "Contested ground: The basis of teacher leadership in two restructuring high schools", The Elementary School Journal, Vol 96, No. $1,1995,47-63$.

[18] A. Lieberman, E. Saxl and M. Miles, "Teachers' Leadership: Ideology and practice" in A. Lieberman (ed.) Building a Professional Culture in Schools, 1988, New York: Teachers College Press.

[19] J. Dewey, How we think, 1933, Boston: D.C. Heath and Company.

[20] D. Schon, Educating the reflective practitioner, 1987, San Fransisco: Jossey-Bass.

[21] J. J. Loughran, Developing Reflective Practice: Learning about Teaching and Learning through Modelling, 1996, London: Falmer Press.

[22] S. D. Brookfield, "Becoming a Critical Reflective Teacher", The JosseyBass higher and education series, 1995, San Fransisco: Jossey-Bass.

[23] A. O'Connor and C. Diggins, On Reflection: Reflective practice for early childhood educators, 2002, New Zealend: Open Mind Publishing.

[24] A. Ghaye and K. Ghaye, Teaching and Learning through Critical Reflective Practice, 1998, London: David Fulton Publisher.

[25] B. Gün, "Quality self-reflection through reflection training", ELT Journal, vol. 65, 2010, pp. 126-135.

[26] C. Brandt, "Integrating feedback and reflection in teacher preparation", 2008, ELT Journal, vol. 62, No. I, pp. 37-46.

[27] D. McCurry, "Technology for critical pedagogy: Beyond self-reflection with video", paper presented at the Society for Information Technology and Teacher Education, 2000, San Diego, CA.

[28] G. E. J. Bolton, Reflective practice: Writing and professional developmen,. United Kingdom: Sage Publication, 2010.

[29] R. Churchill, P. Ferguson, S. Godinho, N. F. Johnson, A. Keddie, W. Letts, , ... M. Vick, Teaching: Making a difference, Sydney: John Wiley Australia, 2011.

[30] A. Graham and R. Phelps, "Being a teacher: Developing teacher identity and enhancing practice through metacognitive and reflective learning processes", Australian Journal of Teacher Education, vol. 27, no. 2, 2003.
[31] P. J. Palmer, The courage to teach: Exploring the inner landscape of a teacher's life, San Fransisco, CA: Jossey-Bass, 1998.

[32] N. Hatton and D. Smith, "Reflection in teacher education: Towards definition and implementation", Teaching and Teacher Education, vol. 11, no. 1, 1995, pp. 33-49.

[33] K. M. Zeichner and D. P. Liston, Reflective teaching: An introduction, New York, NY: Routledge. 1996.

[34] L. Cole and J. Knowles, Researching teaching: Exploring teacher development through reflexive inquiry, Boston: Allyn \& Bacon, 2000.

[35] Ministry of Agency Empowerment, Peraturan Menteri Negara Pendayagunaan Aparatur Negara dan Reformasi Birokrasi No. 16 Tahun 2009 tentang Jabatan fungsional Guru dan Angka Kreditnya, Jakarta: The Government of Republic of Indonesia, 2009.

[36] P. Scales, J. Pickering, L. Senior, K. Headley, P. Garner, and H. Boulton, Continuing professional development in the lifelong learning sector, Glasgow, UK: McGraw-Hill, 2011.

[37] S. Kvale, and S. Brinkmann, InterViews: Learning the craft of qualitative research, Los Angeles: Sage Publications, 2009. 